\title{
Effect of atrial natriuretic factor (ANF) on nicotinic acetylcholine receptor channels in bovine chromaffin cells
}

\author{
J. Bormann 1, *, G. Flügge ${ }^{2}$, and E. Fuchs ${ }^{2}$ \\ 1 Max-Planck-Institut für biophysikalische Chemie, Am Fassberg, D-3400 Göttingen, Federal Republic of Germany \\ 2 Deutsches Primatenzentrum, Kellnerweg 4, D-3400 Göttingen, Federal Republic of Germany
}

\begin{abstract}
Bovine chromaffin cells have binding sites for rat atrial natriuretic factor (ANF), as demonstrated autoradiographically by using the ${ }^{125}$ I-labelled peptide. Patch-clamp recording revealed that ANF reduces acetylcholine (ACh)induced membrane currents in chromaffin cells at physiological membrane potentials. The effect was dose-dependent with the $\mathrm{IC}_{50}$ value being $5.2 \mu \mathrm{M}$ ANF and the Hill coefficient close to 1 . The channel block was absent at positive membrane potentials, indicating a non-competitive interaction of ANF with the open ACh receptor channel. Fragments of ANF had a much less pronounced action, which is possibly due to their structure and molecular charge being different to ANF. The block of nicotinic ACh receptor channels may enable ANF to control the secretion of catecholamines from adrenal chromaffin cells.
\end{abstract}

Key words: Chromaffin cell - Cell culture - Autoradiography - Atrial natriuretic factor - ANF - Patchclamp - Acetylcholine receptor - Ion channel

\section{Introduction}

Atrial natriuretic factor (ANF), a peptide with natriuretic, diuretic and vasorelaxatory properties, is primarily produced and secreted from mammalian atria (see Genest and Cantin 1988 for review). One of its target organs is the adrenal gland where the peptide inhibits aldosterone secretion from the zona glomerulosa cells (Chartier et al. 1984; Atarashi et al. 1984). A physiological influence of the peptide on adrenomedullary cells was indicated by data showing that human ANF binds to human pheochromocytoma cells, where it decreases catecholamine synthesis (Shionoiri et al. 1987). Binding sites for ANF have also been demonstrated autoradiographically in the adrenal medulla of tree shrews and primates (Fuchs et al. 1985, 1986).

Although the synthesis of ANF in bovine chromaffin cells was recently demonstrated (Pruss and Zamir 1987; Ong et al. 1987; Mukoyama et al. 1988), reports on the presence of binding sites for the peptide in the bovine adrenal medulla are inconsistent (Higuchi et al. 1986; Heisler and Morrier 1988). We therefore looked for the binding of rat ANF [rANF $(99-126)]$ to intact bovine adrenal chromaffin cells

* Present address: Merz \& Co., Eckenheimer Landstrasse 100104, D-6000 Frankfurt, Federal Republic of Germany Offprint requests to: J. Bormann at his present address rather than to isolated membranes (Heisler and Morrier 1988) or to dried tissue slices (Higuchi et al. 1986).

The occurrence of ANF in the adrenal medulla has been tentatively ascribed to a role in controlling the acetylcholine (ACh)-mediated secretion of catecholamines (Morel et al. 1988). In order to address this issue, we carried out patchclamp experiments on cultured chromaffin cells. We used the whole-cell configuration of the patch-clamp technique (Hamill et al. 1981) and studied the effect of ANF on nicotinic ACh receptor channels.

\section{Materials and methods}

Cell culture. Chromaffin cells were prepared from bovine adrenal medullae as previously described (Fenwick et al. 1982) and plated on glass cover-slips. Cells were used 1 day after culturing.

Autoradiography. Cells were washed in buffer $(50 \mathrm{mM}$ Tris$\mathrm{HCl} \mathrm{pH} \mathrm{7.4,} 100 \mathrm{mM} \mathrm{NaCl}, 5 \mathrm{mM} \mathrm{MgCl}_{2}, 0.5 \%$ bovine serum albumin, $40 \mu \mathrm{g} / \mathrm{ml}$ bacitracin, $4 \mu \mathrm{g} / \mathrm{ml}$ leupeptin, $2 \mu \mathrm{g} / \mathrm{ml}$ chymostatin, $0.5 \mu \mathrm{g} / \mathrm{ml}$ phenylmethylsulfonylfluoride) and than labelled by incubating for $45 \mathrm{~min}$ in the same buffer to which $2 \mathrm{nM}\left(3-{ }^{125} \mathrm{I}\right]$-iodotyrosil $\left.{ }^{28}\right)$ ANF (specific activity $2,000 \mathrm{Ci} / \mathrm{mmol}$, Amersham, Braunschweig, FRG) had been added. The incubation was carried out according to Quirion et al. (1984). Unspecific binding was detected in the presence of a thousandfold excess of unlabelled ANF. Following the last washing step, the coverslips with cells were dipped into $4 \%$ paraformaldehyde in $0.1 \mathrm{M}$ phosphate buffer, $\mathrm{pH} 7.2$, for $2 \mathrm{~min}$, washed in distilled water, and dried under a cold stream of air. They were then covered with photographic emulsion (NTB 3, Eastman Kodak, Rochester, NY, USA) and exposed for 10 days. After photographic development with D19 and Unifix (Eastman, Kodak, Rochester, NY, USA), cells were stained with hematoxylin, mounted in Eukitt, and inspected under a Zeiss light microscope.

Electrophysiology. The cells were bathed in standard saline and maintained on the stage of an inverted microscope at room temperature. The extracellular saline solution contained (in $\mathrm{mM}$ ): $137 \mathrm{NaCl}, 5.4 \mathrm{KCl}, 1.8 \mathrm{CaCl}_{2}, 1 \mathrm{MgCl}_{2}$, 5 HEPES ( $\mathrm{pH}$ 7.4). Patch pipettes were filled with a solution containing (in $\mathrm{mM}$ ): $120 \mathrm{CsCl}, 20$ tetraethylammonium-Cl, $1 \mathrm{CaCl}_{2}, 2 \mathrm{MgCl}_{2}, 11$ EGTA, 10 HEPES (pH 7.4). We applied drugs to single cells by using a fast-application system (see Bormann and Clapham 1985). Membrane currents were 


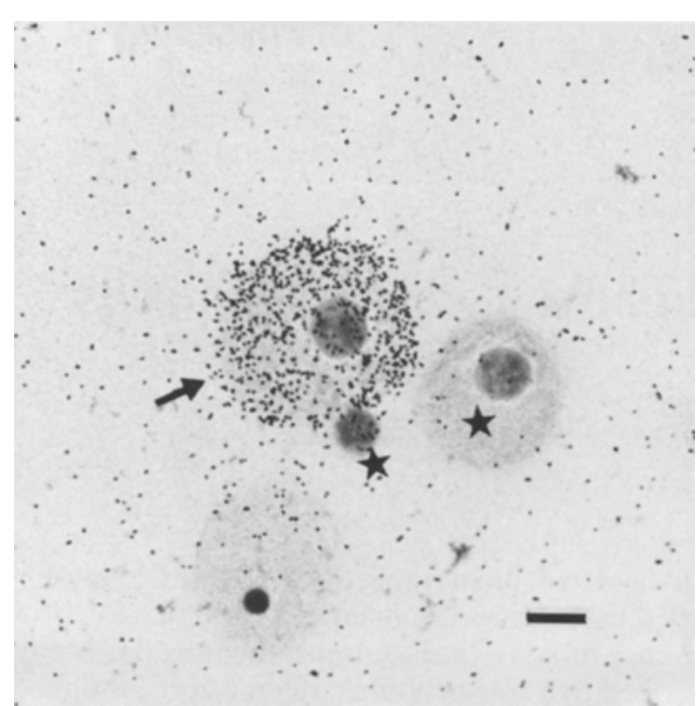

Fig. 1. Bovine chromaffin cell in culture labelled with ${ }^{125}$ I-ANF (arrow). Silver grains are scattered over the cytoplasm and the cell nucleus (grey patch). Note the nuclei of two unlabelled cells (asterisks) in the vicinity of the labelled cells. Non-specific binding of ${ }^{125}$ I-ANF did not occur as judged from experiments, in which an excess of cold ANF was used. Scale bar represents $10 \mu \mathrm{m}$

recorded by means of a standard patch-clamp amplifier (EPC-7, List-Electronic, Darmstadt, FRG) and stored on video tape for later analysis. ANF and its fragments were purchased from Peninsula Laboratories (Belmont, CA, USA) and all other compounds from Sigma (München, FRG). The stability of ANF in the perifusion solution was tested with the instant radioreceptor assay for atrial natriuretic factor (ANAWA Laboratories, Wangen, Switzerland). This assay detects the physiologically active form of ANF which binds to bovine adrenal cortex ANF receptor. ANF dissolved in our HEPES buffer remained in this biologically active form for at least $4 \mathrm{~h}$.

\section{Results}

The presence of ANF binding sites in bovine chromaffin cells is illustrated in Fig. 1, showing an autoradiogram of cultured cells incubated with ${ }^{125}$ I-ANF. Silver grains, which indicate binding of the peptide, are distributed over the cell. In the vicinity, several unlabelled cells are visible.

Figure 2A shows whole-cell currents activated by the application of $10 \mu \mathrm{M} \mathrm{ACh}$ to a chromaffin cell, held at $-70 \mathrm{mV}$ membrane potential. With $4 \mu \mathrm{M}$ ANF included in the ACh solution, the peak-current response to $\mathrm{ACh}$ was changed from $100 \mathrm{pA}$ to $53 \mathrm{pA}$, i.e. a reduction of $47 \%$. From 10 experiments, the average ratio $( \pm S D)$ of currents in presence and absence of ANF was $0.51 \pm 0.03$ (range $0.46-0.56)$. The effect of ANF was readily reversible as seen after applying ACh alone 2 min later. With $20 \mu \mathrm{M}$ ACh, a comparable reduction of the $\mathrm{ACh}$-induced current was found (Fig. 2B), indicating that ANF may not directly interact with the ACh receptor. In this case, the current ratio was $0.59 \pm 0.04$ (range $0.52-0.63, n=7$ ).

The concentration dependence of the ANF effect is illustrated in Fig. 3. The ratio of $\mathrm{ACh}$-induced currents in the presence and absence of ANF, $I / I_{\mathrm{c}}$, is plotted as a function of ANF concentration. Points represent averages from
6-10 determinations at $-70 \mathrm{mV}$ membrane potential. The data obtained with $10 \mu \mathrm{M} \mathrm{ACh}$ (closed circles) did not significantly differ from that at $20 \mu \mathrm{M}$ ACh (open squares). With increasing ANF concentration, the $I / I_{\mathrm{c}}$-ratio decreased, which is consistent with a model, where ANF interacts with the $\mathrm{ACh}$ receptor channel:

Channel (open) $+n \mathrm{ANF} \stackrel{K}{\rightleftharpoons}$ Channel (blocked) $\mathrm{ANF}_{n}$.

Based on this scheme, we have fitted a theoretical curve to the data, as has been reported elsewhere to describe the block of ion channels by drugs (Trube et al. 1986; OhnoShosaku et al. 1987):

$\frac{I}{I_{\mathrm{c}}}=\frac{1}{1+10^{(n \log [\mathrm{ANF}]-\log K)}}$

which is equivalent to

$\frac{I}{I_{\mathrm{c}}}=\frac{1}{1+\left(\frac{[\mathrm{ANF}]}{\mathrm{IC}_{50}}\right)^{n}}$.

From the fit of the $10 \mu \mathrm{M}-\mathrm{ACh}$ data, we obtained a binding constant $K$ for ANF of $36 \mu \mathrm{M}$ and a Hill coefficient of 0.84 , corresponding to an $\mathrm{IC}_{50}$ value of $5.2 \mu \mathrm{M}$.

Rat-ANF is a peptide with a positive molecular net charge. If this were causing its blocking action on $\mathrm{ACh}$ receptor channels at negative membrane potentials, the effect should be voltage dependent. We therefore measured the ANF ratio, $I / I_{c}$, as a function membrane potential. Figure 4 shows the data obtained in the voltage range from $-100 \mathrm{mV}$ to $+50 \mathrm{mV}$. The reduction of ACh-induced currents by $4 \mu \mathrm{M}$ ANF was particularly pronounced at very negative membrane potentials. The peptide became less effective upon depolarizing the cells. At positive voltages, ANF was virtually devoid of any action, again supporting the idea of a direct channel block by the peptide.

The block of nicotinic ACh receptor channels by ANF may, however, not be specific to this channel. We therefore tested the peptide on the GABA receptor channel, a $\mathrm{Cl}^{-}$channel which is also present on chromaffin cells (Bormann and Clapham 1985). ANF did not significantly affect GABA-activated whole-cell currents over a wide range of membrane voltages, indicating that ANF may block specifically the ACh-operated cation channel in bovine chromaffin cells.

Finally, in an attempt to study the structural determinants which cause this block, we used several commercially available peptides each of which constitute part of the amino acid sequence of ANF. We have tested the biological active fragment ANF (103-126) (Atriopeptin II), and the truncated biologically inactive fragments ANF $(99-109)$ and ANF $(116-126)$. Table 1 shows the $I / I_{\mathrm{c}}$ ratios in comparison to ANF for all peptides applied at $10 \mu \mathrm{M}$ concentration in $10 \mu \mathrm{M}$ ACh solutions. The action of the three smaller ANF fragments was less pronounced than that of ANF $(99-126)$, which may be related to their different structure. In addition, the net charge of the peptides resulting from the unbalance of basic and acidic amino acids, may be important. In contrast, human Angiotensin II, a peptide unrelated to ANF, showed only a very weak action on ACh receptor channels (Table 1 ). 

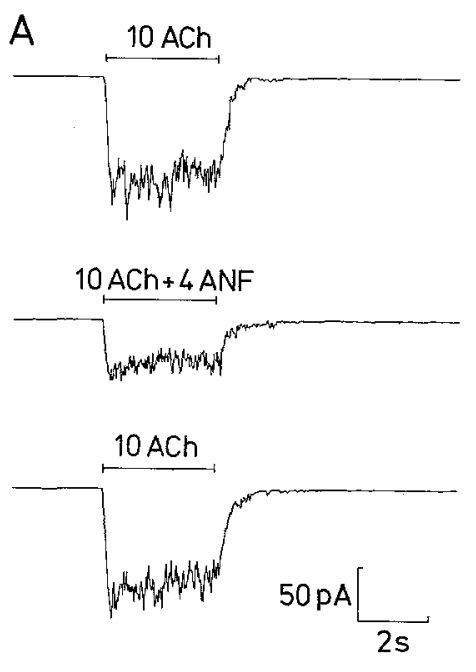
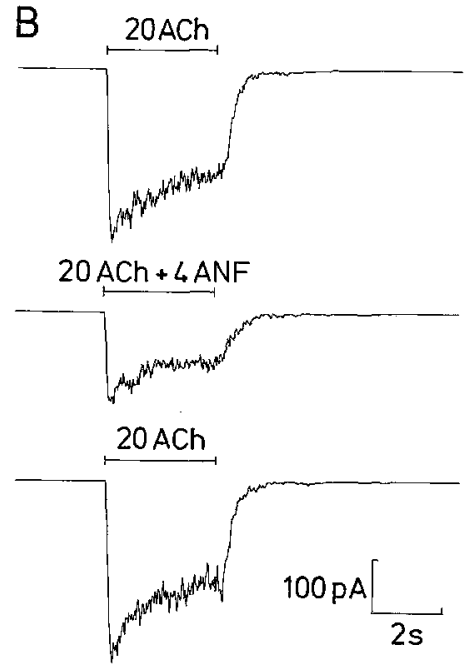

Fig. 2A,B

Reduction of ACh-induced whole-cell currents by ANF . A: Recordings from a chromaffin cell clamped to $-70 \mathrm{mV}$ membrane potential. Top trace shows an inward current triggered by $10 \mu \mathrm{M}$ ACh. With $4 \mu \mathrm{M}$ ANF added to the ACh solution, the peak-current response was reduced by $47 \%$. Bottom trace shows complete recovery from ANF exposure after washing the cell for 2 min with bath solution. B: Same experiment as illustrated in A, except that ACh was applied at $20 \mu \mathrm{M}$ concentration. The response to $\mathrm{ACh}$ was reduced to $54 \%$ in presence of ANF as compared to control

Table 1. Reduction of acetylcholine-induced whole-cell currents by rat ANF (99-126) and angiotensin II

\begin{tabular}{llllll}
\hline & ANF $(99-126)$ & ANF $(103-126)$ & ANF $(99-109)$ & ANF (116-126) & Angiotensin II \\
\hline$I / I_{c}$ & $0.40 \pm 0.05(n=6)$ & $0.86 \pm 0.03(n=4)$ & $0.69 \pm 0.03(n=5)$ & $0.84 \pm 0.04(n=4)$ & $0.90 \pm 0.01(n=3)$ \\
Charge & $4+$ & $2+$ & $3+$ & + & + \\
\hline
\end{tabular}

ACh solutions $(10 \mu \mathrm{M})$ were applied at $-70 \mathrm{mV}$ membrane potential. $I / I_{\mathrm{c}}$ is the ratio of current obtained with $10 \mu \mathrm{M}$ of peptide in ACh solution $(I)$ relative to control current $\left(I_{\mathrm{c}}\right)$. Ratios are expressed as mean \pm SD from $n$ experiments. The number of net charges is given for the peptides as derived from the amino acid composition. The terminology of ANF peptides follows the nomenclature of Dzau et al. (1987)

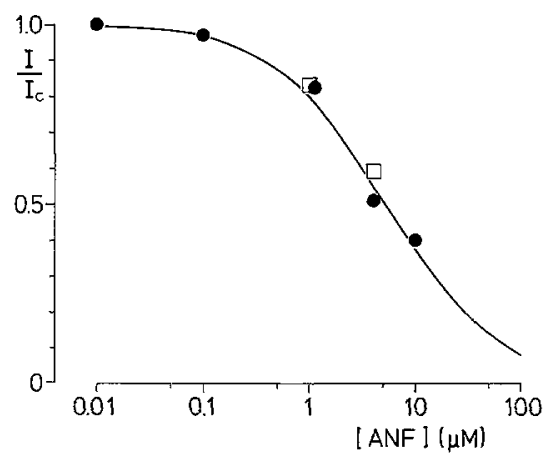

Fig. 3. Concentration dependence of ANF effect on ACh-induced whole-cell currents. The ratio, $I / I_{\mathrm{c}}$, of peak-current amplitudes in presence and absence of ANF is plotted vs. ANF concentration. Each ANF concentration was tested, at $-70 \mathrm{mV}$ membrane potential, on 6-10 cells from different preparations. In two instances, we were able to achieve complete dose-response curves. Closed circles denote experiments with $10 \mu \mathrm{M} \mathrm{ACh}$, whereas open squares are taken from $20 \mu \mathrm{M}$-ACh applications. The curve is a simplex fit of Eq. (2) (see text) to the $10 \mu \mathrm{M}-\mathrm{ACh}$ data, indicating a half maximum inhibitory concentration $\left(\mathrm{IC}_{50}\right)$ of $5.2 \mu \mathrm{M}$ and $n=0.84$ binding sites for ANF

\section{Discussion}

The purpose of the experiments described was twofold. Firstly, we wanted to investigate whether binding sites, which have been demonstrated autoradiographically on dried sections of the adrenal medulla of certain species (Fuchs et al. 1985, 1986), also exist on living bovine

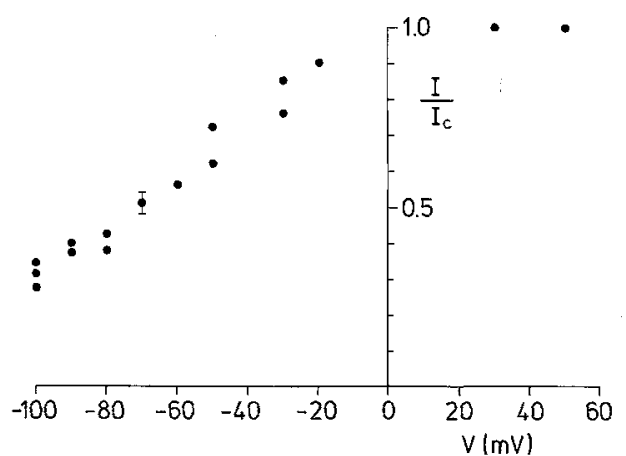

Fig. 4. Voltage sensitivity of ANF-dependent reduction of AChactivated whole-cell currents. The current ratio, $I / I_{\mathrm{c}}$ was determined at various membrane potentials, using $10 \mu \mathrm{M}$ ACh and $4 \mu \mathrm{M}$ ANF. Except at $-70 \mathrm{mV}$, where the mean value from 10 experiments is shown with error bar (SD), data points represent individual measurements on 4 cells from two preparations

chromaffin cells. Secondly, we wanted to address the question of whether ANF binding may have any physiological function in these cells. Our results clearly show that cultured bovine chromaffin cells bind ${ }^{125} \mathrm{I}-\mathrm{ANF}$, indicating an interaction of the peptide with the membrane. The failure, in previous studies, to detect binding of human ANF to dried tissue sections of bovine adrenal medulla (Higuchi et al. 1986) excluded the presence of ANF binding sites. However, an interaction could still take place at the level of ionic channels, which function normally only in living cells. 
Patch-clamp experiments demonstrated that ANF is capable of reducing the activity of nicotinic ACh receptor channels in bovine chromaffin cells. These channels are closely associated with the nerve-stimulated release of catecholamines from adrenal medulla. The decrease of the current flowing through $\mathrm{ACh}$ receptor channels by ANF was concentration-dependent with the half-maximal concentration being $5.2 \mu \mathrm{M}$ ANF and the Hill coefficient close to 1. From the voltage-dependence, the block of ACh receptor channels appeared to be non-competitive. A similar mechanism has been described for several drugs acting as blockers of the nicotinic ACh receptor channel (Adams 1981). As to the molecular determinants of the ANF block, both the structure and charge of the peptide may contribute to its effect. Anion channels like the GABA-operated $\mathrm{Cl}^{-}$-channel were not influenced by ANF, indicating a specific interaction of the peptide with cationic $\mathrm{ACh}$ receptor channels.

Recently, the synthesis and the release of ANF from rat and bovine adrenomedullary chromaffin cells was demonstrated (Pruss and Zamir 1987; Mukoyama et al. 1988). However, the peptide's physiological role in the adrenal medulla is not yet clear. Our data suggest a participation of ANF in the inhibitory control of catecholamine secretion from chromaffin cells. This assumption is supported by earlier reports on an inhibitory effect of ANF in the sympathetic nervous system (Kuchel et al. 1987; Debinski et al. 1987). A new aspect in the understanding of the physiological function is the finding, that the peptide may not only act by a classic ligand-receptor interaction but also by blocking nicotinic $\mathrm{ACh}$ receptor channels. This suggests the existence of a complex paracrine regulation not only of the catecholamine secretory process but also of the release of a variety of other bioactive peptides present in adrenal chromaffin cells such as enkephalins, dynorphin, somatostatin, VIP and others.

Acknowledgenents. We would like to thank Dr. Bert Sakmann for discussion, Frances Edwards for comments on the manuscript and Michael Pilot for culturing chromaffin cells.

\section{References}

Adams PR (1981) Acetylcholine receptor kinetics. J Membr Biol $58: 161-174$

Atarashi K, Mulrow PJ, Franco-Saenz R, Snajpar R, Rapp J (1984) Inhibition of aldosterone production by an atrial extract. Science 224:992-944

Bormann J, Clapham DE (1985) $\gamma$-Aminobutyric acid receptor channels in adrenal chromaffin cells: A patch-clamp study. Proc Natl Acad Sci USA 82:2168-2172

Chartier L, Schiffrin EL, Thibault G, Garcia R (1984) Atrial natriuretic factor inhibits the stimulation of aldosterone secretion by angiotensin II, ACTH and potassium in vitro and angiotensin II-induced steroidogenesis in vivo. Endocrinology 115:2026-2028

Debinski W, Kuchel O, Buu NT, Cantin M, Genest J (1987) Atrial natriuretic factor partially inhibits the stimulated catecholamine synthesis in superior cervical ganglion of the rat. Neurosci Lett $77: 92-96$

Dzau VJ, Baxter JD, Cantin M, DeBold A, Ganten D, Gross K, Husain A, Inagami T, Menard J, Poole S, Robertson JIS, Tang
J, Yamamoto K (1987) Nomenclature for atrial peptides. New Engl J Med 316:1278 - 1279

Fenwick GM, Marty A, Neher E (1982) A patch-clamp study of bovine chromaffin cells and of their sensitivity to acetylcholine. J Physiol (Lond) 331:577-597

Fuchs E, Flügge G, Shigematsu K, Saavedra JM (1985) Binding sites for atrial natriuretic peptide in tree shew and primate adrenal gland. In: Brenner BM, Laragh JH (eds) Biologically active atrial peptides. Raven Press, New York, pp 232-235

Fuchs E, Shigematsu K, Saavedra JM (1986) Binding sites of atrial natriuretic peptide in tree shrew adrenal gland. Peptides 7:873876

Genest J, Cantin M (1988) The atrial natriuretic factor: Its physiology and biochemistry. Rev Physiol Biochem Pharmacol 110:1-145

Hamill OP, Marty A, Neher E, Sakmann B, Sigworth FJ (1981) Improved patch-clamp techniques for high-resolution current recording from cells and cell-free membrane patches. Pflügers Arch 312:85-100

Heisler S, Morrier E (1988) Bovine adrenal medullary cells contain functional atrial natriuretic peptide receptors. Biochem Biophys Res Commun 150:781-787

Higuchi K, Nawata H, Kato K, Ibayashi H, Matsuo H (1986) Alpha-human natriuretic polypeptide ( $\alpha$-hANP) specific binding sites in bovine adrenal gland. Biochem Biophys Res Commun 137:657-663

Kuchel O, Debinski W, Racz K, Buu NT, Garcia R, Cusson J, Larochelle P, Cantin M, Genest J (1987) Minireview: An emerging relationship between peripheral sympathetic nervous activity and atrial natriuretic factor. Life Sci 40:15451551

Morel G, Chabot JG, Garcia-Caballero T, Gossard F, Dihl F, Belles-Isles M, Heisler S (1988) Synthesis, internalization, and localization of atrial natriuretic peptide in rat adrenal medulla. Endocrinology 123:149-158

Mukoyama M, Nakao K, Morii N, Shiono S, Itoh H, Sugawara A, Yamada T, Saito Y, Arai H, Imura H (1988) Atrial natriuretic polypeptide in bovine adrenal medulla. Hypertension 11:692696

Ohno-Shosaku T, Zünkler BJ, Trube G (1987) Dual effects of ATP on $\mathrm{K}^{+}$currents of mouse pancreatic $\beta$-cells. Pflügers Arch 408:133-138

Ong H, Lazure C, Nguyen TT, McNicoll N, Saidah N, Chrétien M, de Léan A (1987) Bovine adrenal chromaffin granules are a site of synthesis of atrial natriuretic factor. Biochem Biophys Res Commun 147:957-963

Pruss RM, Zamir N (1987) Regulated expression of atrial natriuretic peptide-like immunoreactivity in cultured bovine adrenomedullary chromaffin cells. Neurochem Int $11: 299-304$

Quirion R, Dalpe M, de Léan A, Gutkowska J, Cantin M, Genest $\mathrm{J}$ (1984) Atrial natriuretic factor (ANF) binding sites in brain and related structures. Peptides 5:1167-1172

Shionoiri H, Hirawa N, Takasaki I, Ishikawa Y, Minamisawa K, Miyajima E, Kinoshita $Y$, Shimoyama K, Shimonaka M, Ishido $M$, Hirose S (1987) Presence of functional receptors of atrial natriuretic peptide in human pheochromocytoma. Biochem Biophys Res Commun 148:286-291

Trube G, Rorsman P, Ohno-Shosaku T (1986) Opposite effects of tolbutamide and diazoxide on the ATP-dependent $\mathrm{K}^{+}$channel in mouse pancreatic $\beta$-cells. Pflügers Arch 407:493-499

Received November 9, 1988/Received after revision and accepted January 2, 1989 